\title{
Uji in vitro Aktivitas Antibakteri Minyak Atsiri Batang Sereh (Cymbopogon citratus) terhadap Shigella dysenteriae
}

\section{(In vitro Antibacterial Activity of Lemongrass (Cymbopogon citratus) Oil againts Shigella dysenteriae)}

\author{
Yunita Wulansari, Enny Suswati, Septa Surya Wahyudi \\ Program Studi Pendidikan Dokter, Fakultas Kedokteran Universitas Jember \\ Jln. Kalimantan 37, Jember 68121 \\ e-mail: enny_suswati.fk@unej.ac.id
}

\begin{abstract}
Shigella dysenteriae is bacteria that caused diarrhea with high morbidity and mortality. Resistance and toxicity has reported in some antibiotics therapy towards S. dysentriae. Therefore, alternative therapy based on herbal plants is needed. Chymbopogon citratus oil can be used as an antibacterial to Escherichia coli, Klebsiella pneumoniae, Streptococcus mutans, all strains Staphlylococcus sp, Bacillus cereus and Bacillus subtilis. This study aimed to investigate antibacterial activity of $C$. citratus oils on the growth of $S$. dysentriae and its minimum inhibitory concentration (MIC). This type of research was a quasi experimental. Antibacterial activity test performed by diffusion method. Subjects in this study were S. dysentriae. C. citratus oil concentration used were $15 \mu \mathrm{l} / \mathrm{ml}, 20 \mu \mathrm{l} / \mathrm{ml}, 25$ $\mu \mathrm{l} / \mathrm{ml}, 30 \mu \mathrm{l} / \mathrm{ml}, 35 \mu \mathrm{l} / \mathrm{ml}$ and $40 \mu \mathrm{l} / \mathrm{ml}$. Positive control group was given ciprofloxacin $5 \mu \mathrm{l} / \mathrm{ml}$ and a negative control group was given tween-80. Inhibition zone was observed at a concentration of $25 \mu \mathrm{l} / \mathrm{ml}(\mathrm{P} 3)$. The MIC of C. citratus oils againts S. dysentriae was at a concentration of $25 \mu \mathrm{l} / \mathrm{ml}$. Kruskal Wallis analysis showed that $p=0.000$ and $\alpha=0.05$, it was revealed that there were differences between antibacterial activity amoung tested group with different concentration.
\end{abstract}

Keywords: Shigella dysenteriae, Chymbopogon citratus oil, antibacterial

\begin{abstract}
Abstrak
Shigella dysenteriae merupakan bakteri penyebab diare denga angka kesakitan dan kematian tinggi. Terapi antbiotik terhadap $S$. dysenteriae terjadi beberapa resistensi dan toksisitas. Oleh karena itu, diperlukan alternatif terapi berbasis tanaman obat. Minyak atsiri Chymbopogon citratus dapat digunakan sebagai antibakteri terhadap Escherichia coli, Klebsiella pneumonia, Streptococcus mutans, semua strain Staphlylococcus sp, Bacillus cereus, dan Bacillus subtilis. Penelitian ini bertujuan untuk mengetahui aktivitas antibakteri minyak atsiri $C$. citratus terhadap pertumbuhan $S$. dysentriae dan mengetahui konsentrasi hambat minimal (KHM). Jenis penelitian adalah quasi experimental. Uji aktivitas antibakteri dilakukan secara in vitro dengan metode difusi sumuran. Subjek pada penelitian ini adalah S. dysentriae yang dibiakkan pada media Mueller Hinton. Konsentrasi minyak atsiri $C$. citratus yang digunakan adalah $15 \mu \mathrm{l} / \mathrm{ml}, 20 \mu \mathrm{l} / \mathrm{ml}, 25 \mu \mathrm{l} / \mathrm{ml}, 30 \mu \mathrm{l} / \mathrm{ml}, 35 \mu \mathrm{l} / \mathrm{ml}$, dan $40 \mu \mathrm{l} / \mathrm{ml}$. Kelompok kontrol positif diberikan siprofloksasin $5 \mu \mathrm{l} / \mathrm{ml}$ dan kelompok kontrol negatif diberikan tween-80. Zona hambat mulai terbentuk pada pemberian konsentrasi minyak atsiri $C$. citratus $25 \mu \mathrm{l} / \mathrm{ml}$ (P3). Hal ini menunjukkan KHM minyak atsiri $C$. citratus terhadap S. dysenteriae adalah konsentrasi $25 \mu \mathrm{l} / \mathrm{ml}$. Analisis Kruskal Wallis menunjukkan $\mathrm{p}=0,000$ dan $\alpha=0,05$, hal ini mengindikasikan bahwa terdapat perbedaan aktivitas antibakteri pada beberapa konsentrasi uji.
\end{abstract}

Kata kunci: Shigella dysenteriae, Minyak atsiri Chymbopogon citratus, antibakteri 


\section{Pendahuluan}

Diare merupakan salah satu penyakit infeksi yang menjadi masalah kesehatan di dunia. World Health Oranization (WHO) menyebutkan terjadi 1.7 juta kejadian diare di seluruh dunia [1]. Penyebab utama tingginya angka kesakitan dan kematian pada diare adalah disentri basiler [2]. Di negara berkembang, Shigella dysenteriae menjadi penyebab utama disentri basiler. Terapi disentri basiler dengan antibiotik berbeda di setiap daerah karena perbedaan spesies yang menginfeksi maupun adanya resistensi $\mathrm{Di}$ Indonesia, terapi dengan antibiotik siprofloksasin dosis tunggal menunjukkan hasil yang baik. Namun, siprofloksasin tidak boleh diberikan kepada anak dan ibu hamil [3]. Sehingga diperlukan alternatif sebagai upaya menanggulangi resistensi dan membantu terapi pada disentri basiler.

Indonesia memiliki keanekaragaman tanaman yang dapat digunakan sebagai tanaman obat. Salah satu jenis tanaman yang dapat digunakan sebagai bahan antibakteri adalah sereh (Cymbopogon citratus). C. citratus telah digunakan sebagai obat tradisional untuk batuk, malaria, ophtalmia, pneumonia dan gangguan vaskuler. C. citratus juga diketahui dapat digunakan sebagai antidepresan, antioksidan, antiseptik, antibakteri, antifungi, penenang, dan sedatif.

Minyak atsiri $C$. citratus terbukti dapat digunakan sebagai antibakteri terhadap bakteri gram negatif seperti Escherichia coli dan Klebsiella pneumonia juga bakteri gram positif seperti Streptococcus mutans, semua strain Staphlylococcus sp, Bacillus cereus, dan $B$. subtilis [4-5]. Kandungan minyak atsiri $C$. citratus terdiri atas geranial $(40,6 \%)$, neral $(33,7 \%)$, myrecene $(10,3 \%)$, geraniol $(4,6 \%)$, dan sesquiterpene lainnya (8,6\%) [6]. Menurut Onawunmini, senyawa aktif geranial (alpha citral) dan neral (beta citral) yang merupakan golongan terpenoid memiliki aktivitas antibakteri [5]. Penelitian ini bertujuan untuk mengetahui aktivitas antibakteri minyak atsiri $C$. citratus terhadap pertumbuhan $S$. dysentriae dan mengetahui konsentrasi hambat minimal (KHM) minyak atsiri $C$. citratus terhadap pertumbuhan S. dysentriae.

\section{Metode Penelitian}

Penelitian ini diaksanakan di Laboratorium Rekayasa Produksi Hasil Pertanian (RPHP) Fakultas Teknologi Pertanian
Universitas Jember untuk pembuatan minyak atsiri $C$. citratus dengan teknik destilasi uap dan di Laboratorium Mikrobiologi Fakultas Kedokteran Universitas Jember sebagai tempat untuk uji aktivitas antibakteri minyak atsiri $C$. citratus terhadap bakteri $S$. dysentriae. Penelitian dilaksanakan setelah mendapatkan ethical clearance dari komisi etik Fakultas Kedokteran Universitas Jember.

Jenis penelitian yang digunakan berupa quasi experimental. Uji aktivitas antibakteri dilakukan secara in vitro dengan metode difusi sumuran. Subjek pada penelitian ini adalah $S$. dysentriae yang dibiakkan pada media $\mathrm{MH}$ (Mueller Hinton). Suspensi S. dysentriae didapatkan dengan cara mengambil biakan $S$. dysentriae menggunakan ose steril, kemudian dimasukkan dalam aquades steril hingga mencapai kekeruhan yang ekivalen dengan 0,5 standart Mc Farland (setara $1 \times 10^{8} \mathrm{CFU} / \mathrm{ml}$ ). Sampel kemudian dibagi menjadi beberapa kelompok.

Kelompok $\mathrm{P} 1$ diberikan minyak atsiri $C$. citratus konsentrasi $15 \mu \mathrm{l} / \mathrm{ml}$. Kelompok P2 diberikan minyak atsiri $C$. citratus konsentrasi $20 \mu \mathrm{l} / \mathrm{ml}$. Kelompok P3 diberikan minyak atsiri $C$. citratus konsentrasi $25 \mu \mathrm{l} / \mathrm{ml}$. Kelompok P4 diberikan minyak atsiri $C$. citratus konsentrasi $30 \mu \mathrm{l} / \mathrm{ml}$. Kelompok P5 diberikan minyak atsiri $C$. citratus konsentrasi $35 \mu \mathrm{l} / \mathrm{ml}$, dan kelompok P6 diberikan minyak atsiri C. citratus $40 \mu \mathrm{l} / \mathrm{ml}$. Konsentrasi minyak atsiri C. citratus $15 \mu \mathrm{l} / \mathrm{ml}$ didapatkan dari $15 \mu \mathrm{l}$ minyak atsiri $C$. citratus dan ditcampurkan dalam $1 \mathrm{ml}$ tween-80 demikian juga dengan konsentrasi $20 \mu \mathrm{l} / \mathrm{ml}, 25 \mu \mathrm{l} / \mathrm{ml}$, $30 \mu \mathrm{l} / \mathrm{ml}, 35 \mu \mathrm{l} / \mathrm{ml}$, dan $40 \mu \mathrm{l} / \mathrm{ml}$ [7]. Kelompok kontrol positif diberikan siprofloksasin $5 \mu \mathrm{l} / \mathrm{ml}$ dan kelompok kontrol negatif diberikan tween-80.

Analisis statistik pada penelitian ini menggunakan Shapiro-Wilk untuk menguji normalitas data dan uji homogenitas varians data menggunakan uji Levene. Selanjutnya dilakukan uji non parametrik Kruskal Wallis.

\section{Hasil Penelitian}

Aktivitas antibakteri minyak atsiri $C$. citratus terhadap pertumbuhan $S$. dysentriae pada media Mueller Hinton Agar ditunjukkan dengan terbentuknya diameter daya hambat. Diameter daya hambat ditentukan dari daerah bening disekitar sumuran media $\mathrm{MH}$ yang ditumbuhi bakteri S.dysentriae. Minyak atsiri C.citratus dinyatakan mempunyai aktivitas antibakteri apabila diameter daya hambat melebihi diameter sumuran $(>0,76 \mathrm{~cm})$. 


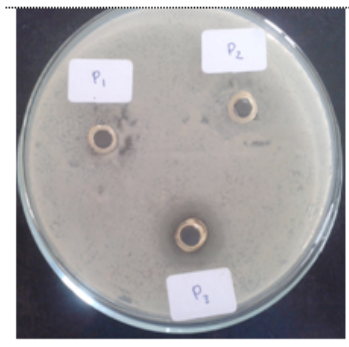

Cawan I

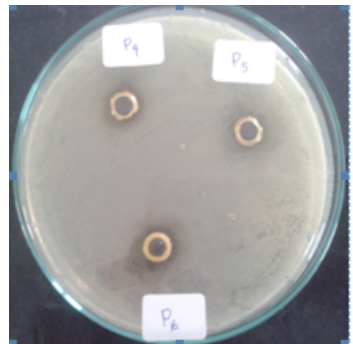

Cawan II
Gambar 1. Diameter daya hambat minyak atsiri C. citratus terhadap pertumbuhan S.dysentriae secara in vitro.

Berikut data yang diperoleh setelah dilakukan penelitian dan pengamatan dari aktivitas antibakteri minyak atsiri C.citratus terhadap pertumbuhan S.dysentriae diperoleh hasil :

Tabel 1. Hasil pengukuran diameter daya hambat minyak atsiri C.citratus terhadap pertumbuhan S.dysentriae secara in vitro

\begin{tabular}{cccccccccc}
\hline Peng & \multicolumn{8}{c}{ Diameter zaona hambat $(\mathrm{cm})$} \\
$\begin{array}{c}\text { ulang } \\
\text { an }\end{array}$ & K- & P1 & P2 & P3 & P4 & P5 & P6 & K+ \\
I & 0.76 & 0.76 & 0.76 & 0.82 & 1.1 & 1.15 & 1.2 & 1.78 \\
II & 0.76 & 0.76 & 0.76 & 1.1 & 1.17 & 1.32 & 1.47 & 1.76 \\
III & 0.76 & 0.76 & 0.76 & 1.58 & 1.45 & 1.54 & 1.9 & 1.8 \\
IV & 0.76 & 0.76 & 0.76 & 1.62 & 1.73 & 1.84 & 1.89 & 2.18 \\
V & 0.76 & 0.76 & 0.76 & 1.87 & 2.05 & 2.17 & 2.58 & 2.53 \\
$\begin{array}{c}\text { Rata- } \\
\text { rata }\end{array}$ & 0.76 & 0.76 & 0.76 & 1.4 & 1.5 & 1.68 & 1.81 & 2.01 \\
\hline
\end{tabular}

Keterangan:

$\mathrm{K}(+)$ : Kelompok kontrol positif (kontak dengan siprofloksasin $5 \mu \mathrm{l} / \mathrm{ml}$ )

$\mathrm{K}(-)$ : Kelompok kontrol negatif (kontak dengan tween-80)

P1 : Perlakuan 1 (kontak dengan minyak atsiri C.citratus konsentrasi $15 \mu \mathrm{l} / \mathrm{ml}$ )

P2: Perlakuan 2 (kontak dengan minyak atsiri C.citratus konsentrasi $20 \mu \mathrm{l} / \mathrm{ml})$

P3 : Perlakuan 3 (kontak dengan minyak atsiri C.citratus konsentrasi $25 \mu \mathrm{l} / \mathrm{ml}$ )

P4: Perlakuan 4 (kontak dengan minyak atsiri C.citratus konsentrasi $30 \mu \mathrm{l} / \mathrm{ml}$ )
P5: Perlakuan 5 (kontak dengan minyak atsiri C.citratus konsentrasi $35 \mu \mathrm{l} / \mathrm{ml}$ )

P6: Perlakuan 5 (kontak dengan minyak atsiri C.citratus konsentrasi $40 \mu \mathrm{l} / \mathrm{ml}$ )

0,76 : Diameter sumuran

Berdasarkan tabel 1 dapat diketahui bahwa minyak atsiri C.citratus mulai membentuk diameter daya hambat pada konsentrasi $25 \mu \mathrm{l} / \mathrm{ml}$ (P3), 30 $\mu \mathrm{l} / \mathrm{ml}$ (P4), 35 $\mu \mathrm{l} / \mathrm{ml}$ (P5), dan $40 \mu \mathrm{l} / \mathrm{ml}$ (P6). Namun pada konsentrasi $15 \mu \mathrm{l} / \mathrm{ml}$ (P1) dan $20 \mu \mathrm{l} / \mathrm{ml}$ (P2) tidak terbentuk diameter daya hambat. Rata-rata diameter daya hambat minyak atsiri C.citratus pada konsentrasi $25 \mu \mathrm{l} / \mathrm{ml}, 30 \mu \mathrm{l} / \mathrm{ml}, 35 \mu \mathrm{l} / \mathrm{ml}$ dan $40 \mu \mathrm{l} / \mathrm{ml}$ secara berturut-turut adalah $1,398 \mathrm{~cm}, ; 1,5 \mathrm{~cm}$; $1,675 \mathrm{~cm}$; dan $1,808 \mathrm{~cm}$. Konsentrasi hambat minimal (KHM) minyak atsiri C.citratus terhadap pertumbuhan S.dysentriae dalam penelitian ini adalah $25 \mu \mathrm{l} / \mathrm{ml}$.

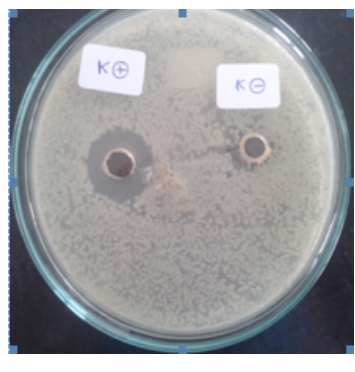

Cawan III

Gambar 2. Diameter daya hambat kontrol positif dan kontrol negatif.

Kontrol positif dalam penelitian ini menggunakan antibiotik siprofloksasin. Interpretasi nilai diameter daya hambat antibiotik siprofloksasin dengan konsentrasi $5 \mu \mathrm{l} / \mathrm{ml}$ adalah, apabila diameter daya hambat $<15 \mathrm{~mm}$, maka bakteri resisten terhadap antibiotik siprofloksasin [8]. Rata-rata diamerter daya hambat antibiotik siprofloksasin terhadap pertumbuhan S.dysentriae adalah $2,01 \mathrm{~cm}$ yang menandakan bahwa bakteri S.dysentriae masih sensitif terhadap antibiotik siprofloksasin. Sedangkan kontrol negatif yang menggunakan tween-80 tidak terbentuk diameter daya hambat.

Berdasarkan uji Kruskal Wallis, dapat diketahui bahwa nilai $p=0,000$ dan nilai $\alpha=0,05$. Nilai $p<\alpha$ menunjukkan bahwa terdapat perbedaan aktivitas antibakteri pada beberapa konsentrasi uji. Perbedaan aktivitas antibakteri pada setiap kelompok konsentrasi dapat diketahui menggunakan uji Post Hoc multiple comparison dengan metode Mann Whitney. Dari hasil uji Post Hoc (tabel 2) dapat diketahui dapat 
dilihat bahwa tidak ada perbedaan diameter daya hambat yang signifikan antara kelompok (K-) dengan P1 dan P2. Peningkatan konsentrasi minyak atsiri C.citratus dari $15 \mu \mathrm{l} / \mathrm{ml}$ (P1) ke 20 $\mathrm{ll} / \mathrm{ml}$ (P2) juga tidak menunjukkan perbedaan diameter daya hambat. Diameter daya hambat mulai ada perbedaan yang bermakna pada peningkatan konsentrasi minyak atsiri C.citratus dari $20 \mu \mathrm{l} / \mathrm{ml}(\mathrm{P} 2) \mathrm{ke} 25 \mu \mathrm{l} / \mathrm{ml}(\mathrm{P} 3)$. Namun pada peningkatan $25 \mu \mathrm{l} / \mathrm{ml}$ (P3) ke $30 \mu \mathrm{l} / \mathrm{ml}$ (P4) tidak menunjukkan adanya perbedaan diameter daya hambat. Demikian juga peningkatan konsentrasi dari 30 $\mathrm{\mu l} / \mathrm{ml}$ (P4) ke $35 \mu \mathrm{l} / \mathrm{ml}$ (P5) dan ke $40 \mu \mathrm{l} / \mathrm{ml}$ (P6) juga tidak menunjukkan perbedaan diameter daya hambat secara bermakna. Hal ini dapat terjadi karena perbedaan konsentrasi P1, P2, P3, P4, P5, dan $P 6$ yang rendah yaitu $5 \mu \mathrm{l} / \mathrm{ml}$ sehingga aktivitas antibakteri yang ditimbulkan hampir sama pada kelompok P3, P4, P5, dan P6.

Kelompok $(\mathrm{K}+)$ dibandingkan dengan $\mathrm{P} 5$ dan P6 menunjukkan tidak terdapat perbedaan diameter daya hambat yang bermakna. Hal tersebut menunjukkan bahwa pada kelompok $35 \mu \mathrm{l} / \mathrm{ml}$ (P5) dan 40 $\mathrm{l} / \mathrm{ml}$ (P6) memiliki aktivitas antibakteri setara dengan siprofloksasin dalam menghambat pertumbuhan S.dysentriae secara in vitro.

Tabel 2. Hasil analisis multiple comparison dengan metode Mann Whitney

\begin{tabular}{|c|c|c|c|c|c|c|c|c|}
\hline Keompok & $\mathrm{kV} \cdot \mathrm{F}$ & $p 1$ & $P 2$ & $P 3$ & P4 & 95 & $P 6$ & $\mathrm{~K} \mid+$ \\
\hline $\mathrm{kN} \cdot \mathrm{H}$ & & 1,000 & 1000 & $0,005^{x}$ & $0,005^{x}$ & $0,005^{x}$ & $0,0005^{x}$ & $0,005^{\prime}$ \\
\hline P1. & 1000 & & 1000 & $0,005^{x}$ & $0,005^{x}$ & $0,005^{x}$ & $0,005^{x}$ & $0,005^{\prime}$ \\
\hline$P 2$ & 1,000 & 1,000 & & $0,005^{x}$ & $0,005^{x}$ & $0,005^{x}$ & $0,005^{x}$ & $0,005^{\circ}$ \\
\hline$P 3$ & $0,005^{x}$ & $0,005^{x}$ & $0,005^{x}$ & & 0,675 & 0,602 & 0,175 & 0,047 \\
\hline P4 & $0,005^{x}$ & $0,005^{x}$ & $0,005^{x}$ & 0,675 & & 0,002 & 0,251 & $0,047^{\circ}$ \\
\hline$p 5$ & $0,005^{x}$ & $0,0055^{x}$ & $0,005^{x}$ & 0,002 & 0,602 & & 0,465 & 0,175 \\
\hline 96 & $0,005^{x}$ & $0,005^{x}$ & $0,005^{x}$ & 0,175 & 0,251 & 0,465 & & 0,754 \\
\hline 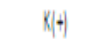 & $0,005^{x}$ & $0,005^{x}$ & $0,005^{x}$ & $0,0477^{x}$ & $0,0477^{x}$ & 0,175 & 0,754 & \\
\hline
\end{tabular}

Keterangan:

* $\quad$ : ada perbedaan signifikan

\section{Pembahasan}

Berdasarkan tabel 1 dapat diketahui bahwa kelompok perlakuan 1 (P1) dengan pemberian konsentrasi minyak atsiri C.citratus $15 \mu \mathrm{l} / \mathrm{ml}$ dan kelompok perlakuan 2 (P2) dengan pemberian konsentrasi minyak atsiri C.citratus $20 \mu \mathrm{l} / \mathrm{ml}$ tidak menunjukkan diameter daya hambat. Nilai $0,76 \mathrm{~cm}$ pada tabel 1 merupakan diameter sumuran yang dibuat oleh peneliti. Minyak atsiri C.citratus mulai menghambat pertumbuhan S.dysentriae pada konsentrasi

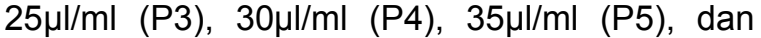
$40 \mu \mathrm{l} / \mathrm{ml}$ (P6). Rata-rata diameter daya hambat yang terbentuk pada pemberian minyak atsiri C.citratus pada kelompok P3 , P4, P5, dan P6 secara berturut sebesar $1,398 \mathrm{~cm}, 1,5 \mathrm{~cm}$, $1,675 \mathrm{~cm}$, dan $1,808 \mathrm{~cm}$. Hal ini sesuai dengan hipotesis peneliti bahwa minyak atsiri sereh $(C$. citratus) memiliki aktivitas antibakteri terhadap pertumbuhan $S$. dysenteriae secara in vitro

Kelompok kontrol positif $(\mathrm{K}+)$ dengan siprofloksasin yang merupakan drug of choice menunjukkan adanya hambatan terhadap pertumbuhan S.dysentriae dengan rata-rata diameter daya hambat sebesar $2,01 \mathrm{~cm}$. Diameter data hambat pada kelompok kontrol positif mengindikasikan bahwa sampel bakteri S.dysentriae sensitif terhadap siprofloksasin. Kontrol negatif tidak menunjukkan diameter daya hambat sehingga tween-80 dapat digunakan sebagai pelarut minyak atsiri C.citratus karena tween-80 tidak mempengaruhi aktivitas antibakteri minyak atsiri $C$.citratus.

Konsentrasi hambat minimal minyak atsiri C.citratus terhadap pertumbuhan S.dysentriae secara in vitro adalah pada kelompok P3. Hal ini menunjukkan bahwa S.dysentriae mulai sensitif terhadap minyak atsiri C.citratus dengan konsentrasi $25 \mu \mathrm{l} / \mathrm{ml}$. S.dysentriae resisten terhadap minyak atsiri C.citratus pada konsentrasi di bawah $25 \mathrm{\mu l} / \mathrm{ml}$.

Setelah didapatkan minyak atsiri $C$. citratus kemudian dibuat sediaan dalam beberapa konsentrasi dengan menambahkan pelarut tween-80. Tween-80 merupakan senyawa ester sorbitol polietilen yang berfungsi sebagai surfaktan. Surfaktan mempunyai kemampuan untuk mempengaruhi sifat permukaan karena memiliki gugus hidrofilik dan lipofilik. Gugus hidrofilik pada surfaktan bersifat polar dan mudah bersenyawa dengan air. Gugus lipofilik bersifat nonpolar dan mudah bersenyawa dengan minyak. Surfaktan dapat menurunkan tegangan permukaan dan meningkatkan laju kelarutan sehingga dapat 
bercampur baik dengan minyak atsiri $C$. citratus. Tween-80 tidak memiliki sifat antifungi maupun antibakteri sehingga tidak akan mengganggu efek bahan uji yang diteliti [9].

Kelompok perlakuan yang diberikan minyak atsiri $C$. citratus akan dibandingkan dengan kelompok kontrol positif. Kontrol positif menggunakan antibiotik siprofloksasin dengan mekanisme kerja menghanbat kerja enzim DNA girase (menghambat topoisomerase II dan IV) bakteri [10]. Minyak atsiri C. citratus yang terbukti memiliki aktivitas antibakteri terhadap S.dysentriae karena mengandung senyawa turunan terpenoid. Komponen minyak atsiri $C$. citratus yang termasuk turunan terpenoid adalah geraniol, geranial, neral, dan $\alpha$-pinene. Senyawa yang dapat menghambat pertumbuhan bakteri adalah senyawa aktif geranial (alpha citral) dan neral (beta citral) dalam minyak atsiri $C$. citratus [5]. Mekanisme kerja antibakteri minyak atsiri C.citratus bekerja sebagai inhibitor kompetitif enzim protease ektraseluler bakteri sehingga tidak terbentuk protein membran sel. Kemudian terjadi lisis dinding sel bakteri dan kebocoran sitoplasma yang mengakibatkan hilangnya material sel sehingga menyebabkan kematian [9-11].

\section{Simpulan dan Saran}

Kesimpulan dari penelitian ini adalah minyak atsiri $C$. citratus memiliki aktivitas antibakteri terhadap pertumbuhan S.dysentriae secara in vitro dengan konsentrasi Hambat Minimum (KHM) adalah $25 \mathrm{ul} / \mathrm{ml}$.

Saran yang dapat diberikan yaitu, perlu dilakukan penelitian lebih lenjut seperti uji in vivo, uji toksisitas, dan juga uji klinis agar minyak atsiri $C$. citratus dapat dimanfaatkan lebih lanjut.

\section{Daftar Pustaka}

[1] World Health Organization [Internet]. Geneva: World Health Organization; 2013. [cited 2015 September 14]. Available form: http://www.who.int/mediacentre/factsheets/fs 330

[2] Kumar V, Abbas AK, Aster JC. Robbins Basic Pathology. 9th ed. Philadelphia : Elsevier Saunders; 2013.

[3] Sya'roni A. Buku Ajar Ilmu Penyakit Dalam: Disentri Basiler. Edisi V. Jakarta: Interna Publishing; 2009.
[4] Naik MI, Fomda BA, Jaykumar E, Bhat JA. Antibacterial Activity of Lemongrass (Chymbopogon citratus) Oil Against Some Selected Pathogenic Baterias. Asian Pacific of Tropical Medicine. 2010. 535-538.

[5] Almeida RBA, Akisue G, Cardoso LMM, Jenqueira JC, dan Jorge. Antimicrobial activity of the essential oil of Cymbopogon citratus (DC) Stapf. on Staphylococcus spp., Streptococcus mutans and Candida spp. Plantas Med. 2013. 15 (4): 474-482.

[6] Taweechaisupapong S, Aieamsaard J, Chitropas P, Khunkitti W. Inhibitory Effect of Lemongrass Oil and its Major Constituents on Candida Biofilm and Germ Tube Formation. South African Journal of Botany. 2012. 95-102.

[7] Feriyanto YE, Sipahutar PJ, Mahfud, dan Prihatini P. Pengambilan Minyak Atsiri dari Daun dan Batang Serai Wangi (Cymbopogon winterianus) Menggunakan Metode Distilasi Uap dan Air dengan Pemanasan Microwave. Jurnal Teknik Pomits. 2013. 2 (1): 93-97.

[8] Vandepitte J, Verhaegen J, Engbaek K, Rohner P, Piot P, dan Heuck CC. Basic Laboratory Procedures In Clinical Bacterylogy. 2nd Edition. Geneva: World Health Organization: 2003. P.120.

[9] Dermawan, A. Polieksietilen 20 Sorbitan Monooleat (Tween 80). Sumatera: Repositori Universitas Sumatera Utara.

[10] Setiabudy R. Golongan Kinolon dan Fluorokuinolon. In Gunawaan SG, editor. Farmakologi dan Terapi. Jakarta : Badan Penerbit FKUI; 2007. P.718-722.

[11] Korenblum E, Goulart F, Rodrigues IA, Abreu F, Lins U, Alves PB, Blank AF, Valoni E, Sebastian GV, Alviano DS, Alviano CS, Seldin L. Antimicrobial action and anticorrosion effect against sulfate reducing bacteria by lemongrass (Cymbopogon citratus) essential oil and its major component, the citral. AMB Express Springer. 2013.

[12] Adesegun AS, Samuel FO, Olawale RG, dan Funmilola SA. Antioxidant activity of the volatile oil of cymbopogon citratus and its inhibition of the partially purified and characterized extracellular protease of Shigella sonnei. American Journal of Research Communication. 2013. 1 (1): 3145. 